Research Article

\title{
Stability of Resistance to Imidacloprid in the Brown Planthopper (Nilaparvata lugens Stål.) from Banyumas, Central Java
}

\author{
Danarsi Diptaningsari')*, Y. Andi Trisyono ${ }^{2)}$, Aziz Purwantoro ${ }^{3)}$, \& Arman Wijonarko ${ }^{2)}$ \\ ${ }^{1)}$ Assessment Institute for Agricultural Technology Lampung, Ministry of Agriculture \\ Jln. Hi. ZA Pagar Alam No. 1A, Rajabasa, Bandar Lampung 35145 Indonesia \\ ${ }^{2)}$ Department of Plant Protection, Faculty of Agriculture, Universitas Gadjah Mada \\ Jln. Flora No. 1 Bulaksumur, Sleman, Yogyakarta 55281 Indonesia \\ ${ }^{3)}$ Department of Agronomy, Faculty of Agriculture, Universitas Gadjah Mada \\ Jln. Flora No. 1 Bulaksumur, Sleman, Yogyakarta 55281 Indonesia \\ *Corresponding author.E-mail: ddanarsi@gmail.com
}

Received March 5, 2019; revised September 11, 2019; accepted January 9, 2020

\begin{abstract}
Imidacloprid is one of the insecticides that has been widely used to control the brown planthopper (Nilaparvata lugens Stål.). The excessive use of insecticides led to the development of insecticide resistance in $N$. lugens. This study was aimed to determine the stability of resistance to imidacloprid in $N$. lugens from Banyumas, Central Java Province. The five generations of selection increased the resistance ratio (RR) from 46.20-fold to 150.39 -fold. To assess the stability of resistance to imidacloprid in $N$. lugens, the fifth generation was further reared for 10 generations without exposure to insecticides. The stability studies showed that resistance to imidacloprid was unstable with a decrease of resistance from 150.39-fold to 38.14-fold after 10 generations without selections. Continuous selections with imidacloprid for three generations could increase the resistance level from 150.39-fold to 216.13-fold. The unstable resistance could be managed by removing the selection pressure for a period of time or switching to insecticides with different mode of actions. Information regarding resistance stability would be useful to determine an effective resistance management strategies in $N$. lugens.
\end{abstract}

Keywords: imidacloprid; Nilaparvata lugens; resistance; unstable

\section{INTRODUCTION}

Brown planthopper, Nilaparvatalugens Stål. (Hemiptera: Delphacidae) is an important pest of rice in Asia (CABI, 2019). N. lugens have been widely spread in Indonesia, i.e. Java Island, Bali, Lampung, South Sumatra, West Kalimantan, South Kalimantan, and Central Sulawesi (BB Padi, 2019). The control technique of $N$. lugens in Indonesia mainly depends on the use of insecticides. Imidacloprid is one of the active ingredients from the neonicotinoid insecticide class commonly used for controlling $N$. lugens. Imidacloprid is a systemic insecticide that translocates rapidly through plant tissues following application (Gervais et al., 2019). Imidacloprid was first introduced in 1990 (Matsumura \& Sanada-Morimura, 2010) and began to be registered in Indonesia for controlling N. lugens since 1992 (Ditjen PSP, 2017).

Long term insecticide application causes the control of $N$. lugens to be ineffective when it is applied according to recommended doses. This finding reveals that $N$. lugens has been resistant. Several studies revealed that the field population of $N$. lugens has been resistant to insecticides (Wen et al., 2009; Puinean et al., 2010; Bao et al., 2016). The population of $N$. lugens from China, Thailand, and Vietnam showed a high level of resistance to imidacloprid with a resistance ratio between 57-2029 fold (Bao et al., 2016; Zhang et al., 2016). Previous studies of $N$. lugens resistance to imidacloprid were reported in Indonesia, i.e. Banyumas ( $R R=27.7$-fold), Cilacap $(\mathrm{RR}=29.37$-fold $)$, Karawang $(\mathrm{RR}=108.1$-fold $)$, and East Java (RR = 3-fold) (Baehaki et al., 2016; Londingkene et al., 2016a; Surahmat et al., 2016). The development of pest resistance causes the use of insecticides was ineffective, hence causes economic losses.

The stability of resistance is important to be studied to determine the effectiveness of the pest control strategies, by rearing the selected insects without 
exposure to insecticides for some generations (Lan \& Zhao, 2001). Ullah \& Shad (2017) reported that the resistance to chlorfenapyr and triazophos in Oxycarenus hyalinipennis was unstable, whereas the resistance to fipronil and emamectin benzoate was stable. The resistance to acetamiprid in Bemisia tabaci was stable without selection pressure (Basit et al., 2011). Kavi et al. (2014) reported that the resistance to imidacloprid in Musca domestica was unstable and decreased after several months.

Management of pest resistance to insecticides requires a systematic and comprehensive strategy. Successful management of resistance depends on several factors, including knowledge about the stability of pest resistance to insecticides (Roush \& Hoy, 1990). This knowledge can be used as a basis for resistance management strategies that will be developed to anticipate and slow the rate of resistance development. This study was aimed to determine the stability of resistance to imidacloprid in $N$. lugens from Banyumas, Central Java Province. This study could provide important information regarding the stability of resistance to imidacloprid in $N$. lugens in Indonesia which could be used as a basis for sustainable management of $N$. lugens.

\section{MATERIALS AND METHODS}

\section{Insects}

The insects used in this study were the resistant and the susceptible populations of $N$. lugens. The resistant population was collected in 2014 from Banyumas Regency, Central Java Province. This population was reared in a laboratory over 44 generations without selection. The susceptible population was collected since 1986 from Sleman Regency, Special Region of Yogyakarta then maintained in laboratories without selection and without any addition of field population.

\section{Mass Rearing of Nilaparvata lugens}

The mass rearing of resistant and susceptible populations of $N$. lugens used the rearing method established in the Sub Laboratory of Pesticides Toxicology, Faculty of Agriculture, Universitas Gadjah Mada, Yogyakarta. N. lugens were reared using rice seedlings (Ciherang variety) as a diet at the temperature of $27^{\circ} \mathrm{C}$, the relative humidity of $70-80 \%$, and photoperiod of 12:12 (L:D). A hundred pairs of $N$. lugens were placed in a plastic jar (24 $\mathrm{cm}$ in diameter, $30 \mathrm{~cm}$ in height) containing rice seeds (5-7 days old) for laying eggs. After the eggs hatched and the rice became yellow, the nymphs were transferred into a new plastic jar containing new rice seeds. Rice seedlings were regularly replaced every 4 days by taking the old rice seeds and then placing them upside down on the supporting wire thus the remaining nymphs would migrate to the new seeds. The emerged adults were immediately transferred to plastic jars containing 5-7 days of rice seeds for rearing to the next generation.

\section{Insecticide}

The insecticide used in the test and selection of $N$. lugens was an imidacloprid commercial formulation (Confidor 5 WP, PT Bayer Indonesia).

\section{Resistance Selection}

The third instar nymphs of $N$. lugens from the resistant population were selected over eight consecutive generations $\left(\mathrm{F}_{45}-\mathrm{F}_{52}\right)$ using imidacloprid at concentrations of 100-600 ppm. Resistance selection was conducted by using the leaf dipping method. Rice seeds 5-7 days old were dipped in an insecticide solution for 15 seconds then air-dried for 15 minutes. Rice seeds that have been treated were then put in plastic cups $(10 \mathrm{~cm}$ in diameter, $11 \mathrm{~cm}$ in height) filled with water to maintain the seed freshness. The third instar nymphs of $N$. lugens was placed into a plastic cup containing rice seeds that had been treated with insecticide. The number of $N$. lugens used in each generation of selection were 144-400 insects according to their availability. Insect mortality was recorded up to 120 hours after treatment (HAT). The alive insects were transferred into plastic cups containing rice seeds without insecticide to continue their propagation. In each generation of selection, some insects were used for further selection and some insects were used for the resistance test.

\section{Toxicity Bioassay \\ Preliminary Bioassay}

A preliminary bioassay was conducted to determine the concentrations causing $5-99 \%$ mortality of the insects for application in the resistance bioassay. The insect used for the preliminary bioassay was the third instar nymph of $N$. lugens from the resistant and susceptible populations. A preliminary bioassay was performed in a series of concentrations ranging from 0-800 ppm using the leaf dipping method. 
The number of insects used in this bioassay was 250-350 (50 nymphs for each concentration). Mortality was recorded up to 168 HAT.

\section{Resistance Bioassay}

The third instar of $N$. lugens from the resistant and susceptible populations was used in the resistance bioassay. The bioassay was carried out using the leaf dipping method. The number of insects used was 552-726 (60-80 nymphs for each concentration). Mortality was recorded up to 168 HAT.

\section{Toxicity Data Analysis}

Probit analysis (Finney, 1971) by the POLOPlus program was used to calculate $\mathrm{LC}_{50}$ values at 168 HAT. Mortality data were corrected with the Abbotts Formula (Abbotts, 1925). The $\mathrm{LC}_{50}$ values between treatments were not significantly different if the $95 \%$ confidence intervals value is overlapped. The resistance ratio (RR) was calculated by comparing the $\mathrm{LC}_{50}$ of the resistant population and the $\mathrm{LC}_{50}$ of the susceptible population.

\section{Resistance Stability}

The stability of resistance to imidacloprid in $N$. lugens was determined based on the $\mathrm{LC}_{50}$ of the resistant population after being selected over five generations $\left(\mathrm{F}_{45}-\mathrm{F}_{49}\right)$, and then some insects were further reared without insecticide exposure over ten generations $\left(\mathrm{F}_{50}-\mathrm{F}_{59}\right)$. Resistance bioassay and $\mathrm{LC}_{50}$ values were calculated for each generation using the method described before. The decrease in resistance was measured by calculating the value of Decrease in Resistance (DR) or estimated response to selection (Falconer \& Mackay, 1996) which could be used to calculate the average response per generation at $\mathrm{LC}_{50}$ values after removing the selection. The $\mathrm{DR}-$ value was estimated as:

$$
\mathrm{DR}=\left[\log \left(\text { final } \mathrm{LC}_{50}\right)-\log \left(\text { initial } \mathrm{LC}_{50}\right)\right] / \mathrm{n}
$$

where the final $\mathrm{LC}_{50}$ is the $n$ generation of $\mathrm{LC}_{50}$ after reared without selection $\left(\mathrm{G}_{59}\right)$, the initial $\mathrm{LC}_{50}$ is the $n$ generation of $\mathrm{LC}_{50}$ which has been selected $\left(\mathrm{G}_{45}\right)$, and $n$ is the number of generations reared without selection (ten generations). The decrease in resistance to imidacloprid with a low DR value (negative) revealed that the resistance to imidacloprid in $N$. lugens is unstable. The estimated number of generations required for a 10 times decrease of the $\mathrm{LC}_{50}$ value was calculated based on the reciprocal of DR or $\mathrm{DR}^{-1}$ values (Ullah \& Shad, 2017). To test the changes of resistance, selection with imidacloprid was continued on some insects over three generations on the $\mathrm{G}_{50}-\mathrm{G}_{52}$ and $\mathrm{LC}_{50}$ values were calculated for each generation.

\section{RESULT AND DISCUSSION}

Preliminary bioassay on the resistant population of $N$. lugens obtained the concentration for the resistance bioassay was ranged from 0-640 ppm, and in the susceptible population, the concentration was ranged from $0-80 \mathrm{ppm}$. The resistance test of imidacloprid for the susceptible and Banyumas populations, with and without selection were presented in Table 1. Selection with imidacloprid was carried out over eight consecutive generations $\left(\mathrm{G}_{45}-\mathrm{G}_{52}\right)$ with concentrations ranged from 100 $600 \mathrm{ppm}$. Toxicity tests were performed on each generation. In the fifth generation after selection $\left(G_{49}\right)$, the selection pressure was removed for some insects and further reared over ten generations without selection $\left(\mathrm{G}_{50}-\mathrm{G}_{59}\right)$ to determine the stability of the resistance. The resistance ratio of the Banyumas population increased from 46.20 -fold $\left(\mathrm{G}_{45}\right)$ to 150.39 -fold $\left(\mathrm{G}_{49}\right)$ compared to the susceptible population. The resistance ratio value then decreased quite rapidly in the first fifth generations after the selection was removed $\left(\mathrm{G}_{50}-\right.$ $\left.\mathrm{G}_{54}\right)$. In the sixth generation without selection $\left(\mathrm{G}_{55}\right)$, the resistance ratio decreased to 46.18 -fold, was near to the initial resistance ratio before selection (46.20-fold). In the seventh to tenth generations, after the selection was removed $\left(\mathrm{G}_{56}-\mathrm{G}_{59}\right)$, the resistance ratio fluctuated but did not decrease significantly. The selection with imidacloprid was continued using some insects over three generations $\left(\mathrm{G}_{50}-\mathrm{G}_{52}\right)$ to asses the stability of resistance, increased the resistance ratio from 150.39 -fold $\left(\mathrm{G}_{49}\right)$ to 216.13 -fold $\left(\mathrm{G}_{52}\right)$ (Figure 1).

Selection to imidacloprid in $N$. lugens could increase the resistance ratio at $\mathrm{G}_{45}$ to $\mathrm{G}_{49}$. However, the resistance was unstable with a low DR of -0.06 . The resistance ratio decreased after the selection pressure was removed on ten generations $\left(\mathrm{G}_{50}-\mathrm{G}_{59}\right)$. The estimated number of generations required for a ten times decrease in $\mathrm{LC}_{50}$ was 16.67 generations (Table 2). The change in resistance was also indicated by an increase in the resistance ratio when the selection pressure was continued at $G_{50}$ to $G_{52}$ (Figure 1). Resistance to imidacloprid is a factor leads to an 
Table 1. Response of Nilaparvata lugens from Banyumas, Central Java, to imidacloprid with and without selection

\begin{tabular}{|c|c|c|c|c|c|c|}
\hline Population & $\mathrm{n}$ & Slope $( \pm$ SE) & $\mathrm{LC}_{50}(95 \% \mathrm{CI})(\mathrm{ppm})$ & $\chi^{2}(\mathrm{df})$ & $\mathrm{P}$ & $\mathrm{RR}^{\mathrm{a}}$ \\
\hline $\begin{array}{l}\text { Susceptible } \\
\text { Banyumas }^{\text {b }}\end{array}$ & 552 & $1.22( \pm 0.20)$ & $0.56(0.24-0.95)$ & $5.71(6)$ & 0.46 & \\
\hline $\mathrm{F} 45(\mathrm{~S})$ & 633 & $0.77( \pm 0.14)$ & $25.87(12.33-50.03)$ & $1.08(7)$ & 0.99 & 46.20 \\
\hline F46 (S) & 660 & $0.72( \pm 0.08)$ & $38.58(27.07-57.87)$ & $4.73(7)$ & 0.69 & 68.89 \\
\hline F47 (S) & 660 & $1.09( \pm 0.09)$ & $52.75(39.32-70.25)$ & $5.35(7)$ & 0.62 & 94.20 \\
\hline F48 (S) & 660 & $1.24( \pm 0.13)$ & $72.34(52.20-96.62)$ & $4.56(7)$ & 0.71 & 129.18 \\
\hline F49 (S) & 666 & $1.17( \pm 0.17)$ & $84.22(57.06-120.97)$ & $1.30(7)$ & 0.99 & 150.39 \\
\hline F50 (S) & 726 & $1.03( \pm 0.14)$ & $106.88(73.40-160.12)$ & $1.80(7)$ & 0.97 & 190.86 \\
\hline$F_{51}(\mathrm{~S})$ & 726 & $1.07( \pm 0.14)$ & $113.14(79.91-166.53)$ & $3.22(7)$ & 0.86 & 202.04 \\
\hline $\mathrm{F}_{52}(\mathrm{~S})$ & 726 & $1.16( \pm 0.19)$ & $121.03(85.00-175.13)$ & $3.67(7)$ & 0.82 & 216.13 \\
\hline F50 (WS) & 666 & $1.48( \pm 0.18)$ & $72.84(51.81-95.61)$ & $4.33(7)$ & 0.74 & 130.07 \\
\hline F51 (WS) & 660 & $1.27( \pm 0.13)$ & $52.94(38.45-70.08)$ & $1.04(7)$ & 0.99 & 94.54 \\
\hline F52 (WS) & 660 & $1.62( \pm 0.18)$ & $47.68(35.15-61.13)$ & $3.15(7)$ & 0.87 & 85.14 \\
\hline F53 (WS) & 660 & $1.44( \pm 0.17)$ & $41.92(28.90-55.76)$ & $5.18(7)$ & 0.64 & 74.86 \\
\hline F54 (WS) & 660 & $1.18( \pm 0.11)$ & $33.97(24.23-45.72)$ & $2.54(7)$ & 0.92 & 60.66 \\
\hline F55 (WS) & 660 & $1.29( \pm 0.11)$ & $25.86(19.39-33.54)$ & $2.70(7)$ & 0.91 & 46.18 \\
\hline F56 (WS) & 660 & $1.53( \pm 0.13)$ & $22.64(17.45-28.57)$ & $5.20(7)$ & 0.64 & 40.43 \\
\hline F57 (WS) & 660 & $1.56( \pm 0.17)$ & $25.18(17.84-33.00)$ & $6.57(7)$ & 0.47 & 44.96 \\
\hline F58 (WS) & 660 & $1.29( \pm 0.10)$ & $19.61(15.02-25.12)$ & $4.94(7)$ & 0.67 & 35.02 \\
\hline F59(WS) & 660 & $1.55( \pm 0.13)$ & $21.36(16.35-27.05)$ & $5.51(7)$ & 0.60 & 38.14 \\
\hline
\end{tabular}

Remarks: ${ }^{a} \mathrm{RR}$ (resistance ratio), comparison between $\mathrm{LC}_{50}$ from Banyumas and $\mathrm{LC}_{50}$ from susceptible population. ${ }^{\mathbf{b}} \mathrm{S}=$ with selection; $\mathrm{WS}=$ without selection.

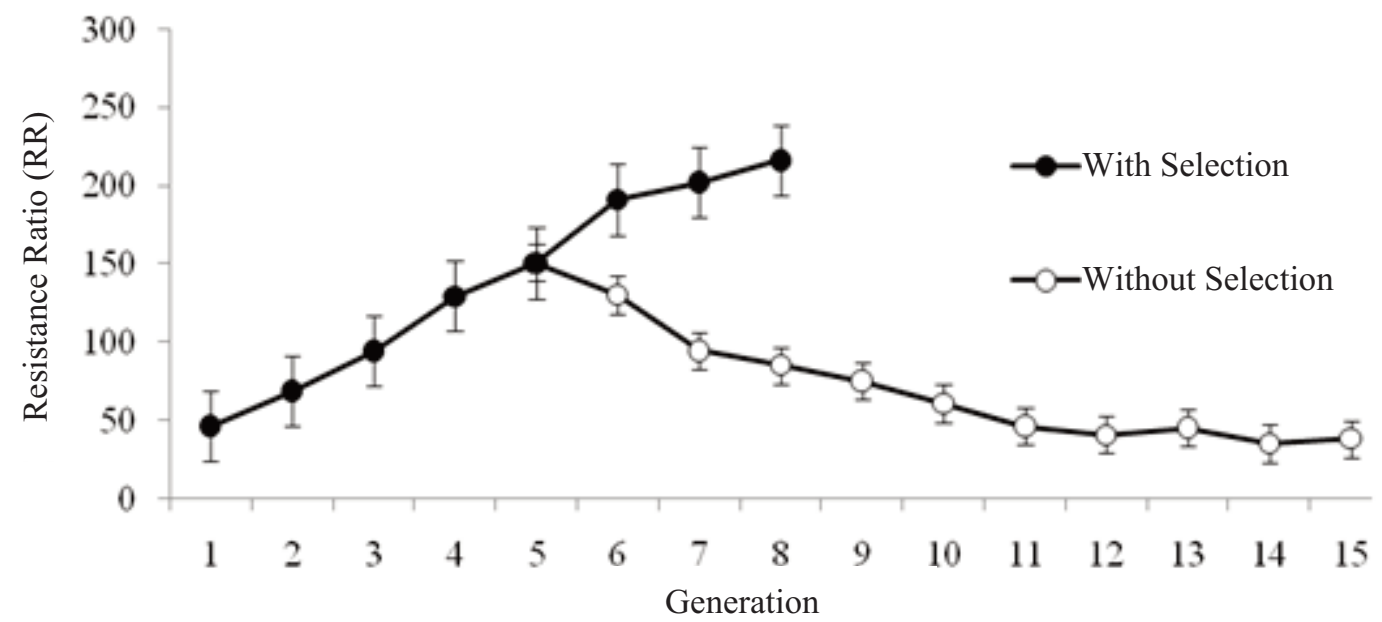

Figure 1. Resistance fluctuation to imidacloprid in Nilaparvata lugens from Banyumas, Central Java, with and without selection pressure; the error bars represent the $95 \%$ confidence intervals of the resistance ratios

outbreak of $N$. lugens in recent years (Gao et al., 2014; Zhang et al., 2017). Imidacloprid has been registered since 1992 and used to control $N$. lugens in Indonesia (Ditjen PSP, 2017). The excessive and widely used of imidacloprid also occurs in other Asian countries (Wang \& Wang, 2007). Selection pressure in the laboratory in this study revealed that $N$. lugens has a fairly high level of resistance to imidacloprid in fifth generations. Wang et al. (2009) reported an increase of resistance of $N$. lugens to imidacloprid from 200-1298-fold with selection over 23 generations. In this study, a further selection of $N$. lugens for three generations $\left(\mathrm{G}_{50}-\mathrm{G}_{52}\right)$ could increase the resistance level.

The rapid increase in resistance ratio is partly due to an increase in the rate of imidacloprid detoxification, by increasing the activity of enzymes that play a role in detoxification. Resistance to imidacloprid in $N$. lugens was reported due to detoxification caused by increased activity of the 
Table 2. Response of Nilaparvata lugens from Banyumas, Central Java, to imidacloprid

\begin{tabular}{|c|c|}
\hline & Value \\
\hline $\begin{array}{l}\text { Number of generation } \\
\text { without selection }\end{array}$ & 10 \\
\hline Initial LC50a $(95 \% \mathrm{CI})(\mathrm{ppm})$ & $84.22(57.06-120.97)$ \\
\hline Final LC50 $(95 \%$ CI $)(\mathrm{ppm})$ & $21.36(16.35-27.05)$ \\
\hline Initial Slope ${ }^{a}( \pm S E)$ & $1.17( \pm 0.17)$ \\
\hline Final Slope $^{\mathbf{b}}( \pm \mathrm{SE})$ & $1.55( \pm 0.13)$ \\
\hline Initial $\mathrm{RR}^{\mathrm{a}}$ & 150.39 \\
\hline Final RR ${ }^{b}$ & 38.14 \\
\hline $\mathrm{DR}^{\mathbf{c}}$ & -0.06 \\
\hline $\mathrm{GR}^{\mathbf{d}}$ & 16.67 \\
\hline
\end{tabular}

Remarks:

${ }^{a}$ LC50 value, slope and initial RR (resistance ratio) were determined at $\mathrm{G}_{45}$.

${ }^{b} \mathrm{LC} 50$ value, slope and final RR (resistance ratio) were determined at G59.

'Decrease in resistance.

${ }^{\mathrm{d}}$ Estimated number of generations needed to decrease 10-fold LC50 value (DR-1).

cytochrome P450 monooxygenase enzyme (Wen et al., 2009; Puinean et al., 2010; Zhang et al., 2017) and because of changes in the target site (Liu et al., 2005; Wen et al., 2009). Two P450 monooxygenase genes, CYP6AY1 and CYP6ER1, are reported causing the resistance of $N$. lugens to imidacloprid in China, Thailand, and Vietnam (Bao et al., 2016). Recent studies of the resistance mechanism to insecticides involve the process of DNA methylation and histone modification as epigenetic events of metabolic resistance (Bass et al., 2014; Oppold \& Müller, 2017).

The insect resistance to insecticides is controlled by genetic factors. The initial population that is susceptible to insecticides is generally dominated by susceptible insects and only a small proportion that has resistant genes. Through a selection process with continuous application of insecticides, the initial susceptible population develops into a population dominated by resistant insects (Matsumura, 1985). After being selected over five generations in this study, selection pressures were then removed and observed over ten generations. The decrease of the resistance ratio occurs rapidly in the first six generations after the selection was removed. The instability of resistance might be related to the existence of the fitness cost in the population of $N$. lugens (Londingkene et al., 2016b). Differences in the level of dominance between alleles, initial gene frequency, and relative fitness are factors that might play a role in reducing the level of resistance in pest populations (Afzal et al., 2015).

On the seventh to tenth generations, after the selection was removed, the resistance ratio fluctuated but did not decrease significantly. This finding revealed the presence of homozygous alleles for resistance before selection pressure was removed (Ullah \& Shad, 2017). Besides, imidacloprid formulation is easily soluble in water hence most likely to be carried by irrigation water into streams, lakes, and other water sources might cause increased persistence of these insecticides in the environment. Imidacloprid is a systemic insecticide, has long-term residual activity, and could produce persistent selection pressure that leads to the resistance of $N$. lugens (Liu et al., 2003). This would contribute to the stability of pest resistance thus the resistance ratio did not decrease significantly even though the application of imidacloprid was stopped.

Information regarding resistance stability would be useful to determine an effective resistance management strategies in $N$. lugens. Resistance to imidacloprid in $N$. lugens was unstable with a decrease of the resistance ratio after the selection pressure was removed for ten generations. Unstable resistance could be managed by removing the selection pressure for a period of time or switching to insecticides with different mode of actions (Ullah $\&$ Shad, 2017). The strategy in managing resistance to imidacloprid in $N$. lugens in Indonesia must be specific to the target population and environment, i.e. through proper ecosystem management, polyculture cultivation, the use of refugia as natural enemy habitats, reduce the use of imidacloprid (neonicotinoid groups) within a period of time, and switching insecticides with different mode of actions. A largescale resistance management strategy needs to be implemented to successfully manage pests sustainably.

\section{CONCLUSION}

Resistance to imidacloprid in $N$. lugens from Banyumas population was unstable with a small DR value $(-0.06)$. The resistance ratio to imidacloprid in $N$. lugens has decreased from 150.39-fold to 38.14-fold after the selection pressure was removed for ten generations. Further selection with imidacloprid for three generations increased the resistance ratio from 150.39-fold to 216.13-fold. Unstable resistance could be managed by removing the selection 
pressure for a period of time or by switching the insecticides with different mode of actions. Proper environmental management could be applied as an alternative management strategy of $N$. lugens to slow the rate of resistance development.

\section{ACKNOWLEDGEMENT}

The author thanks Sriyanto Harjanto for assisting to maintain the susceptible population of $N$. lugens. This paper is partly the first author's doctoral dissertation program through a scholarship from the Indonesian Agency for Agricultural Research and Development, the Ministry of Agriculture.

\section{LITERATURE CITED}

Abbotts, W.S. 1925. A Method of Computing the Effectiveness of an Insecticide. Journal of Economic Entomology 18: 256-267.

Afzal, M.B., N. Abbas, \& S.A. Shad. 2015. Inheritance, Realized Heritability and Biochemical Mechanism of Acetamiprid Resistance in the Cotton Mealybug, Phenacoccus solenopsis Tinsley (Homoptera: Pseudococcidae). Journal of Pesticide Biochemistry and Physiology 122: 44-49.

Baehaki, S.E., E.H. Iswanto, \& D. Munawar. 2016. Resistensi Wereng Cokelat terhadap Insektisida yang Beredar di Sentra Produksi Padi. Penelitian Pertanian Tanaman Pangan 35: 99-108.

Bao, H., H. Gao, Y. Zhang, D. Fan, J. Fang, \& Z. Liu. 2016. The Roles of CYP6AY1 and CYP6ER1 in Imidacloprid Resistance in the Brown Planthopper: Expression Levels and Detoxification Efficiency. Journal of Pesticide Biochemistry and Physiology 129: 70-74.

Basit, M., A.H. Sayyed, M.A. Saleem, \& S. Saeed. 2011. Cross-resistance, Inheritance, and Stability of Resistance to Acetamiprid in Cotton Whitefly, Bemisia tabaci Genn (Hemiptera: Aleyrodidae). Crop Protection 30: 705-712.

Bass, C., A.M. Puinean, C.T. Zimmer, L.M. Field, S.P. Foster, O. Gutbrod, R. Nauen, R. Slater, \& M.S. Williamson. 2014. The Evolution of Insecticide Resistance in Peach Potato Aphid, Myzus persicae. Insect Biochemistry and Molecular Biology 51: 41-51.

BB Padi (Balai Besar Penelitian Tanaman Padi). 2019. Peta Sebaran Serangan Wereng Batang Coklat.http://www.bbpadi.litbang.pertanian.go.id /index.php/pemetaan/content/444peta-sebaranserangan-wereng-batang-coklat.html, modified $02 / 02 / 2019$.
CABI (Centre for Agriculture and Bioscience International). 2019. Distribution Table of Nilaparvata lugens (Brown Planthopper). http://www.cabi.org/isc/datasheet/36301.html, modified 02/02/2019.

Ditjen PSP (Direktorat Jenderal Prasarana dan Sarana Pertanian). 2017. Pestisida Pertanian dan Kehutanan. Kementerian Pertanian RI, Jakarta. 1096 p.

Falconer, D.S. \& T.F.C. Mackay. 1996. Introduction to Quantitative Genetics. Longman. England. $464 \mathrm{p}$.

Finney, D.J. 1971. Probit Analysis. 3rd Edition. Cambridge University Press. London. 333 p.

Gao, H., F. Lu, B. Zhai, M. Lu, W. Liu, F. Zhu, X. Wu, G. Chen, \& X. Zhang. 2014. Outbreaks of the Brown Planthopper Nilaparvata lugens (Stål) in the Yangtze River Delta: Immigration or Local Reproduction?. Plos One 9: 1-12.

Gervais, J.A., B. Luukinen, K. Buhl \& D. Stone. 2019. Imidacloprid Technical Fact Sheet. http://npic.orst.edu/factsheets/archive/imidaclop rid.html, modified 22/01/2019.

Kavi, L.A.K., P.E. Kaufman, \& J.G. Scott. 2014. Genetics and Mechanisms of Imidacloprid Resistance in House Flies. Journal of Pesticide Biochemistry and Physiology 109: 64-69.

Lan, Y.Q. \& S.X. Zhao. 2001. The Stability of Resistance to Three Pyrethroids in Spodoptera exigua Hübner. Chinese Journal of Pesticide Science 6: 77-80.

Liu, Z.W., Z.J. Han, Y.C. Wang, L.C. Zhang, H.W. Zhang, \& C.J. Liu. 2003. Selection for Imidacloprid Resistance in Nilaparvata lugens (Stål): Crossresistance Patterns and Possible Mechanisms. Pest Management Science 59: 1355-1359.

Liu, Z., M.S. Williamson, S.J. Lansdell, I. Denholm, Z. Han, \& N.S. Millar. 2005. A Nicotinic Acetylcholine Receptor Mutation Conferring Target-site Resistance to Imidacloprid in Nilaparvata lugens (Brown Planthopper). PNAS 102: $8420-8425$.

Londingkene, J.A., Y.A. Trisyono, Witjaksono, \& E. Martono. 2016a. Resistance to Imidacloprid and Effect of Three Synergist on the Resistance Level of Brown Planthopper, p.1-5. In T.R. Nuringtyas, R. Roto, A. Widyaparaga, \& M. Mahardika (eds.), Advances of Science and Technology for Society: Proceedings of the 1st International Conference on Science and Technology 2015 (ICST-2015). AIP Conference Proceedings, Yogyakarta. 
Londingkene, J.A., Y.A. Trisyono, Witjaksono, \& E. Martono. 2016b. Relative Fitness and Feeding Capacity of Imidacloprid Resistant Nilaparvata lugens. Jurnal Perlindungan Tanaman Indonesia 20: 43-49.

Matsumura, F. 1985. Toxicology of Insecticides. 2nd Edition. Plenum Press, New York. 598 p.

Matsumura, M. \& S. Sanada-Morimura. 2010. Recent Status of Insecticide Resistance in Asian Rice Planthoppers. Japan Agricultural Research Quarterly 44: 225-230.

Oppold, A.M. \& R. Müller. 2017. Epigenetics: A Hidden Target of Insecticides, p. 313-324. In H. Verlinden (ed.), Advances in Insect Physiology. Elsevier, London.

Puinean, A.M., I. Denholm, N.S. Millar, R. Nauen, \& M.S. Williamson. 2010. Characterization of Imidacloprid Resistance Mechanisms in the Brown Planthopper, Nilaparvata lugens Stal (Hemiptera: Delphacidae). Journal of Pesticide Biochemistry andPhysiology 97: 129-132.

Roush, R.T. \& M.A. Hoy. 1990. Laboratory, Glasshouse and Field Studies of Artificially Selected Carboxyl Resistance in Metaseuilus occidentalis. Journal of Economic Entomology 74: 142-147.

Surahmat, E.C., Dadang \& D. Prijono. 2016. Kerentanan Wereng Batang Cokelat (Nilaparvata lugens) dari Enam Lokasi di Pulau Jawa terhadap Tiga Jenis insektisida. Jurnal Hama Penyakit Tumbuhan Tropika 16: 71-81.
Ullah, S. \& S.A. Shad. 2017. Toxicity of Insecticides, Cross-resistance and Stability of Chlorfenapyr Resistance in Different Strains of Oxycarenus hyalinipennis Costa (Hemiptera: Lygaeidae). Crop Protection 99: 132-136.

Wang, Y.H \& M.H. Wang. 2007. Factors Affecting the Outbreak and Management Tactics of Brown Planthopper, Nilaparvata lugens (Stål) in China in Recent Years. Pesticide Science and Administration 29: 49-54.

Wang, Y.H., S.G. Wu, Y.C. Zhu, J.C. Feng, Y. Liu, X.P. Zhao, Q. Wang, Z.L.X.P. Bo, \& J.L. Shen. 2009. Dynamics of Imidacloprid Resistance and Cross-resistance in the Brown Planthopper, Nilaparvata lugens. Pest Management Science 131: 20-29

Wen, Y., Z. Liu, H. Bao, \& Z. Han. 2009. Imidacloprid Resistance and Its Mechanisms in Field Populations of Brown Planthopper, Nilaparvata lugens Stål in China. Journal of Pesticide Biochemistry and Physiology 94: 3642.

Zhang, J., Y. Zhang, Y. Wang, Y. Yang, X. Cang, \& Z. Liu. 2016. Expression Induction of P450 Genes by Imidacloprid in Nilaparvata lugens: A Genome-scale Analysis. Journal of Pesticide Biochemistry and Physiology 132: 59-64.

Zhang, X., X. Liao, K. Mao, P. Yang, D. Li, E. Alia, \& H. Wan. 2017. The Role of Detoxifying Enzymes in Field-evolved Resistance to Nitenpyram in the Brown Planthopper Nilaparvata lugens in China. Crop Protection 94: 106-114. 